\title{
The Structural Basis for Induction of VanB Resistance
}

\author{
Steven D. Dong, Markus Oberthür, Heather C. Losey, John W. Anderson, Ulrike S. Eggert, \\ Mark W. Peczuh, Christopher T. Walsh, and Daniel Kahne \\ Department of Chemistry, Princeton University, Princeton, NJ 08544 \\ Department of Biological Chemistry and Molecular Pharmacology, Harvard Medical School, Boston, MA \\ 02115
}

\section{Supporting Information}

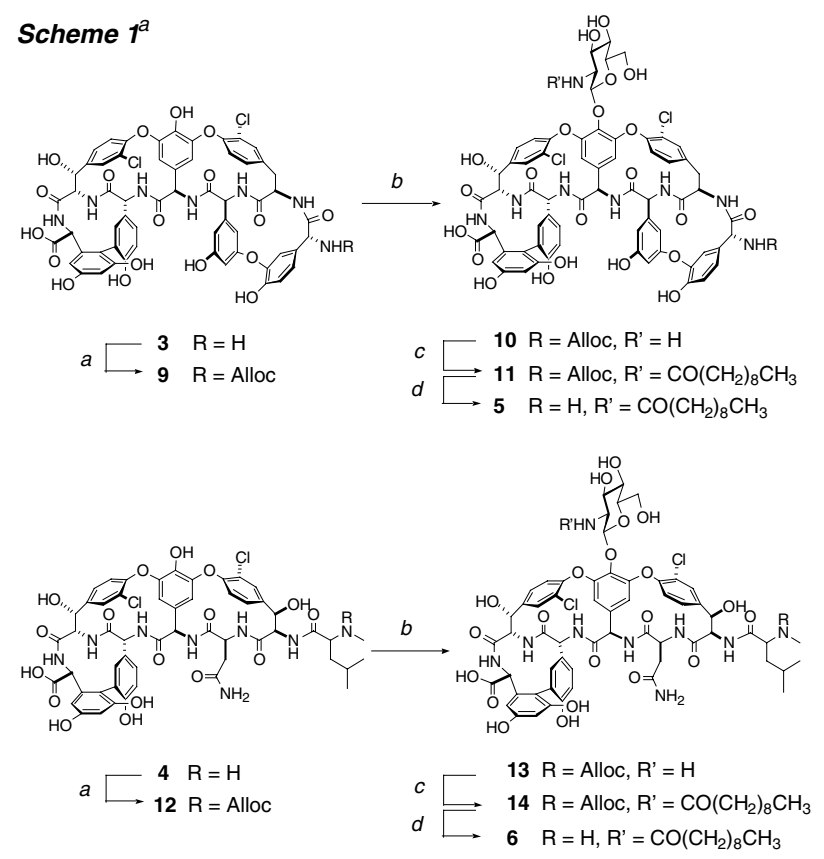

${ }^{a}$ Conditions: (a) alloc succinimide (2 eq), $\mathrm{Et}_{3} \mathrm{~N}, \mathrm{DMF}, 3 \mathrm{~h}, 69 \%$ (9), 73\% (12). (b) $2.8 \mathrm{mM}$ UDP 2- $\mathrm{NH}_{2}-$ Glc (4 eq and 3 eq relative to 9 and 12, respectively), $5 \mu \mathrm{M} \mathrm{GtfE,} \mathrm{pH} 9.0$ buffer containing $75 \mathrm{~mm}$ Tricine, $2.5 \mathrm{~mm}$ tris-(2-carboxyethyl)-phosphine, $1 \mathrm{mg} / \mathrm{mL}$ bovine serum albumin, $37{ }^{\circ} \mathrm{C}$, 40 h, 57\% (10), $69 \%$ (13). (c) decanoyl succinimide (3 eq), Et ${ }_{3} \mathrm{~N}, \mathrm{DMF}, 16$ h, 57\% (11), 55\% (14). (d) $\mathrm{Me}_{2} \mathrm{NH} \cdot \mathrm{BH}_{3}$ (6 eq), $\mathrm{Pd}\left(\mathrm{PPh}_{3}\right)_{4}(0.4 \mathrm{eq}), \mathrm{DMF}, 30 \mathrm{~min}, 66 \%$ (5), $69 \%$ (6). 


\section{General Methods}

Unless otherwise stated, all chemicals were purchased from Aldrich or Sigma and used without further purification. Vancomycin was a generous gift from Merck. Teicoplanin was purchased from Advanced Separation Technologies, Inc.

Analytical HPLC was performed on a Hewlett Packard 1100 series instrument using a Phenomenex Luna $5 \mu \mathrm{C} 18$ column $(250 \times 4.6 \mathrm{~mm})$. Glycopeptide compounds were monitored at an absorbance of $285 \mathrm{~nm}$. To monitor the progress of the reactions, a linear gradient $(0-80 \%$ $\mathrm{CH}_{3} \mathrm{CN}$ in $\mathrm{H}_{2} \mathrm{O} / 0.1 \%$ trifluoroacetic acid over $20 \mathrm{~min}$ ) was used. Reference retention time: teicoplanin aglycone (11.2 $\mathrm{min})$.

Preparative HPLC was performed using a Hitachi L-6200A pump, a Waters 484 tunable absorbance detector and a Phenomenex Luna $5 \mu \mathrm{C} 18$ column $(250 \times 21 \mathrm{~mm})$ or on a Varian ProStar instrument using a Phenomenex Luna $10 \mu \mathrm{C} 18$ column $(250 \times 50 \mathrm{~mm})$.

NMR spectra were recorded on a Varian Inova 500MHz VNMR spectrometer at 313K.

Mass spectra (ESI) were obtained at the Mass Spectroscopy facility at the Department of Chemistry, Princeton University.

\section{Twenty-two-hour minimum inhibitory concentrations (MICs)}

MICs were determined against strains grown in brain-heart-infusion broth in a microdilution format according to NCCLS guidelines: Methods for Dilution Antimicrobial Susceptibility Tests for Bacteria that Grow Aerobically (approved standard, NCCLS Document M7-A4, National Committee for Clinical Laboratory Standards, Wayne, PA, ed. 4, 1997).

\section{Compounds}

Teicoplanin aglycone (3) was prepared from teicoplanin by acid hydrolysis (Boger, D. L. et al. $J$. Am. Chem. Soc. 2000, 122, 10047.) and purified by preparative HPLC. Vancomycin aglycone (4) was prepared by acid hydrolysis of vancomycin (trifluoroacetic acid/ $\mathrm{H}_{2} \mathrm{O} 9: 1$, room temp., $18 \mathrm{~h}$ ) and purified by preparative HPLC. UDP-2-amino-2-deoxy glucose was obtained by deprotection $\left(\mathrm{Et}_{3} \mathrm{~N} / \mathrm{MeOH} / \mathrm{H}_{2} \mathrm{O}, 1: 2: 2,3\right.$ days) of the $N$-trifluoroacetyl protected analog (Sala, R. F.; MacKinnon, S. L.; Palcic, M. M.; Tanner, M. E. Carbohydrate Res. 1998, 306, 127.). Decanoyl 
succinimide was prepared by DCC-mediated coupling of decanoic acid and $\mathrm{N}$-hydroxy succinimide.

$\boldsymbol{N}^{1}$-Alloc teicoplanin aglycone (9): To a solution of teicoplanin aglycone (3) $(0.9 \mathrm{~g}, 0.75 \mathrm{mmol})$ in DMF (10 mL) was added $\mathrm{Et}_{3} \mathrm{~N}(0.14 \mathrm{~mL}, 1 \mathrm{mmol})$ and alloc succinimide (300 mg, $\left.1.5 \mathrm{mmol}\right)$. The mixture was stirred at room temperature for $3 \mathrm{~h}$ and precipitated with $\mathrm{Et}_{2} \mathrm{O}(400 \mathrm{~mL})$. After filtration, the residue was dissolved in DMF $(10 \mathrm{~mL})$ and purified by preparative HPLC to give 9 (660 mg, 69\%) as a pale brown powder; retention time (HPLC): $15.1 \mathrm{~min}$; MS (ESI) for $\mathrm{C}_{62} \mathrm{H}_{49} \mathrm{Cl}_{2} \mathrm{~N}_{7} \mathrm{O}_{20}(1283.0): 1284[\mathrm{M}+\mathrm{H}]^{+}$.

$N^{1}$-Alloc $\mathrm{C}_{6}{ }_{6}$-O-(2-amino-2-deoxy- $\beta$-D-glucosyl) teicoplanin aglycone (10): In a total volume of $405 \mathrm{~mL}, 2.8 \mathrm{mM}$ UDP-2-amino-2-deoxy glucose $(670 \mathrm{mg}, 1.12 \mathrm{mmol})$ and $0.63 \mathrm{mM}$ compound $9(330 \mathrm{mg}, 257 \mu \mathrm{mol})$ were incubated with $75 \mathrm{mM}$ Tricine (pH 9.0), $2.5 \mathrm{mM}$ tris-(2carboxyethyl)-phosphine, $1 \mathrm{mg} / \mathrm{mL}$ bovine serum albumin, and $5 \mu \mathrm{M} \mathrm{GtfE}$ for $40 \mathrm{~h}$ at $37^{\circ} \mathrm{C}$. The volume of the solution was carefully reduced under reduced pressure at $40^{\circ} \mathrm{C}$ and the remaining cloudy mixture was lyophilized. The residue was extracted by addition of DMF (300 ml), stirring of the mixture at room temperature for $8 \mathrm{~h}$, filtration and removal of most of the DMF by evaporation to a final volume of ca. $20 \mathrm{~mL}$. After the addition of water $(20 \mathrm{~mL})$, the mixture was filtered and purified by preparative HPLC to furnish 10 (212 mg, 57\% yield, 78\% yield based on $73 \%$ conversion) as a white solid; retention time (HPLC): 12.0 min; $\mathrm{MS}$ (ESI) for $\mathrm{C}_{68} \mathrm{H}_{60} \mathrm{Cl}_{2} \mathrm{~N}_{8} \mathrm{O}_{24}$ (1444.2): $1445[\mathrm{M}+\mathrm{H}]^{+}$.

$N^{1}$-Alloc $\mathrm{C}_{6}{ }^{4}$-O-(2-NH-decanoyl-2-deoxy- $\beta$-D-glucosyl) teicoplanin aglycone (11): Tо a solution of glycopeptide 10 (36 mg, $25 \mu \mathrm{mol})$ in DMF $(0.5 \mathrm{~mL})$ was added $\mathrm{Et}_{3} \mathrm{~N}(10 \mu \mathrm{l}, 75$ $\mu \mathrm{mol})$ and decanoyl succinimide $(21 \mathrm{mg}, 75 \mu \mathrm{mol})$ under argon. The mixture was stirred at room temperature for $24 \mathrm{~h}$ and purified by preparative HPLC: 11 (23 mg, 57\%) as a white solid; retention time (HPLC): $16.2 \mathrm{~min}$; MS (ESI) for $\mathrm{C}_{78} \mathrm{H}_{78} \mathrm{Cl}_{2} \mathrm{~N}_{8} \mathrm{O}_{25}$ (1598.4): $1622[\mathrm{M}+\mathrm{H}+\mathrm{Na}]^{+}$, 1305 [M - Glc-2NH-decanoyl + Na] $]^{+}$ 
$\mathrm{C}_{6}{ }^{4}$-O-(2-NH-decanoyl-2-deoxy- $\beta$-D-glucosyl) teicoplanin aglycone (5): Compound 11 ( $24 \mathrm{mg}$, $15 \mu \mathrm{mol})$ was dissolved in DMF $(0.5 \mathrm{~mL})$ under argon. After the addition of $\mathrm{Pd}\left(\mathrm{PPh}_{3}\right)_{4}(7 \mathrm{mg}, 6$ $\mu \mathrm{mol})$ and $\mathrm{Me}_{2} \mathrm{NH} \cdot \mathrm{BH}_{3}(5.3 \mathrm{mg}, 90 \mu \mathrm{mol})$, the mixture was stirred for $30 \mathrm{~min}$ in the dark, diluted with DMF, filtered and purified by preparative HPLC: 5 (15 mg, 66\%) as a white solid; retention time (HPLC): $13.4 \mathrm{~min}$; MS (ESI) for $\mathrm{C}_{74} \mathrm{H}_{74} \mathrm{Cl}_{2} \mathrm{~N}_{8} \mathrm{O}_{23}(1514.3): 1537[\mathrm{M}+\mathrm{Na}]^{+}$.

$N^{1}$-Alloc vancomycin aglycone (12): To a solution of vancomycin aglycone (4) (0.86 g, 0.75 mmol) in DMF $(10 \mathrm{~mL})$ was added $\mathrm{Et}_{3} \mathrm{~N}(0.14 \mathrm{~mL}, 1 \mathrm{mmol})$ and alloc succinimide $(300 \mathrm{mg}, 1.5$ $\mathrm{mmol})$. The mixture was stirred at room temperature for $3 \mathrm{~h}$ and precipitated with $\mathrm{Et}_{2} \mathrm{O}$ (400 $\mathrm{mL})$. After filtration, the residue was dissolved in DMF $(10 \mathrm{~mL})$ and purified by preparative HPLC to give 12 (670 mg, 73\%) as a white powder; retention time (HPLC): $14.3 \mathrm{~min}$; MS (ESI) for $\mathrm{C}_{57} \mathrm{H}_{56} \mathrm{Cl}_{2} \mathrm{~N}_{8} \mathrm{O}_{19}(1228.0): 1229[\mathrm{M}+\mathrm{H}]^{+}$.

$N^{1}$-Alloc $\mathrm{C}_{6}{ }_{6}$-O-(2-amino-2-deoxy- $\beta$-D-glucosyl) vancomycin aglycone (13): In a total volume of $229 \mathrm{~mL}, 2.8 \mathrm{mM}$ UDP-2-amino-2-deoxy glucose (380 mg, $0.68 \mathrm{mmol})$ and $1 \mathrm{mM}$ compound 12 (282 mg, $0.23 \mathrm{mmol})$ were incubated with $75 \mathrm{mM}$ Tricine $(\mathrm{pH} \mathrm{9.0),} 2.5 \mathrm{mM}$ tris-(2carboxyethyl)-phosphine, $1 \mathrm{mg} / \mathrm{mL}$ bovine serum albumin, and $5 \mu \mathrm{M} \mathrm{GtfE}$ for $40 \mathrm{~h}$ at $37^{\circ} \mathrm{C}$. The volume of the solution was carefully reduced under reduced pressure and the remaining cloudy mixture lyophilized. The residue was extracted by addition of DMF ( $300 \mathrm{ml})$ and stirring at room temperature for $8 \mathrm{~h}$, filtration and removal of most of the DMF by evaporation to a final volume of ca. $20 \mathrm{~mL}$. After the addition of water $(20 \mathrm{~mL})$, the mixture was filtered and purified by preparative HPLC to furnish $\mathbf{1 3}$ (220 mg, 69\% yield, 83\% yield based on 83\% conversion) as a white solid; retention time (HPLC): $12.1 \mathrm{~min}$; MS (ESI) for $\mathrm{C}_{63} \mathrm{H}_{67} \mathrm{Cl}_{2} \mathrm{~N}_{9} \mathrm{O}_{23}$ (1389.2): $1389[\mathrm{M}]^{+}$; diagnostic ${ }^{1} \mathrm{H}$ NMR peak (500 MHz, $d_{6}$-DMSO, $\left.313 \mathrm{~K}\right): \delta=5.55\left(\mathrm{~d}, 1 \mathrm{H}, J_{1,2}=7.3 \mathrm{~Hz}\right.$, glucose H$1)$.

$N^{1}$-Alloc $\mathrm{C}_{6}^{4}$-O-(2-NH-decanoyl-2-deoxy- $\beta$-D-glucosyl) vancomycin aglycone (14): Tо a solution of glycopeptide 13 (42 mg, $30 \mu \mathrm{mol})$ in DMF $(0.7 \mathrm{~mL})$ was added $\mathrm{Et}_{3} \mathrm{~N}(12 \mu \mathrm{l}, 90$ $\mu \mathrm{mol})$ and decanoyl succinimide ( $25 \mathrm{mg}, 90 \mu \mathrm{mol})$ under argon. The mixture was stirred at room temperature for $24 \mathrm{~h}$ and purified by preparative HPLC: 14 (25 mg, 55\%) as a white solid; 
retention time (HPLC): $15.8 \mathrm{~min}$; $\mathrm{MS}$ (ESI) for $\mathrm{C}_{73} \mathrm{H}_{85} \mathrm{Cl}_{2} \mathrm{~N}_{9} \mathrm{O}_{24}(1543.4): 1556[\mathrm{M}+\mathrm{Na}]^{+}, 1250$ $[\mathrm{M}-\mathrm{Glc}-2 \mathrm{NH}-\text { decanoyl }+\mathrm{Na}]^{+}$.

$\mathrm{C}_{6}{ }^{4}$-O-(2-NH-decanoyl 2-deoxy- $\beta$-D-glucosyl) vancomycin aglycone (6): Compound 14 (19 $\mathrm{mg}, 12 \mu \mathrm{mol})$ was dissolved in $\mathrm{DMF}(0.5 \mathrm{~mL})$ under argon. After the addition of $\operatorname{Pd}\left(\mathrm{PPh}_{3}\right)_{4}(6$ $\mathrm{mg}, 5 \mu \mathrm{mol})$ and $\mathrm{Me}_{2} \mathrm{NH} \cdot \mathrm{BH}_{3}(4.3 \mathrm{mg}, 72 \mu \mathrm{mol})$, the mixture was stirred for $30 \mathrm{~min}$ in the dark, diluted with DMF, filtered and purified by preparative HPLC: 6 (12 mg, 69\%) as a white solid; retention time (HPLC): $13.0 \mathrm{~min}$; $\mathrm{MS}$ (ESI) for $\mathrm{C}_{69} \mathrm{H}_{81} \mathrm{Cl}_{2} \mathrm{~N}_{9} \mathrm{O}_{22}(1459.3): 1460[\mathrm{M}+\mathrm{H}]^{+}, 1144$ $[\mathrm{M}-\text { Glc-2NH-decanoyl }]^{+}$. 


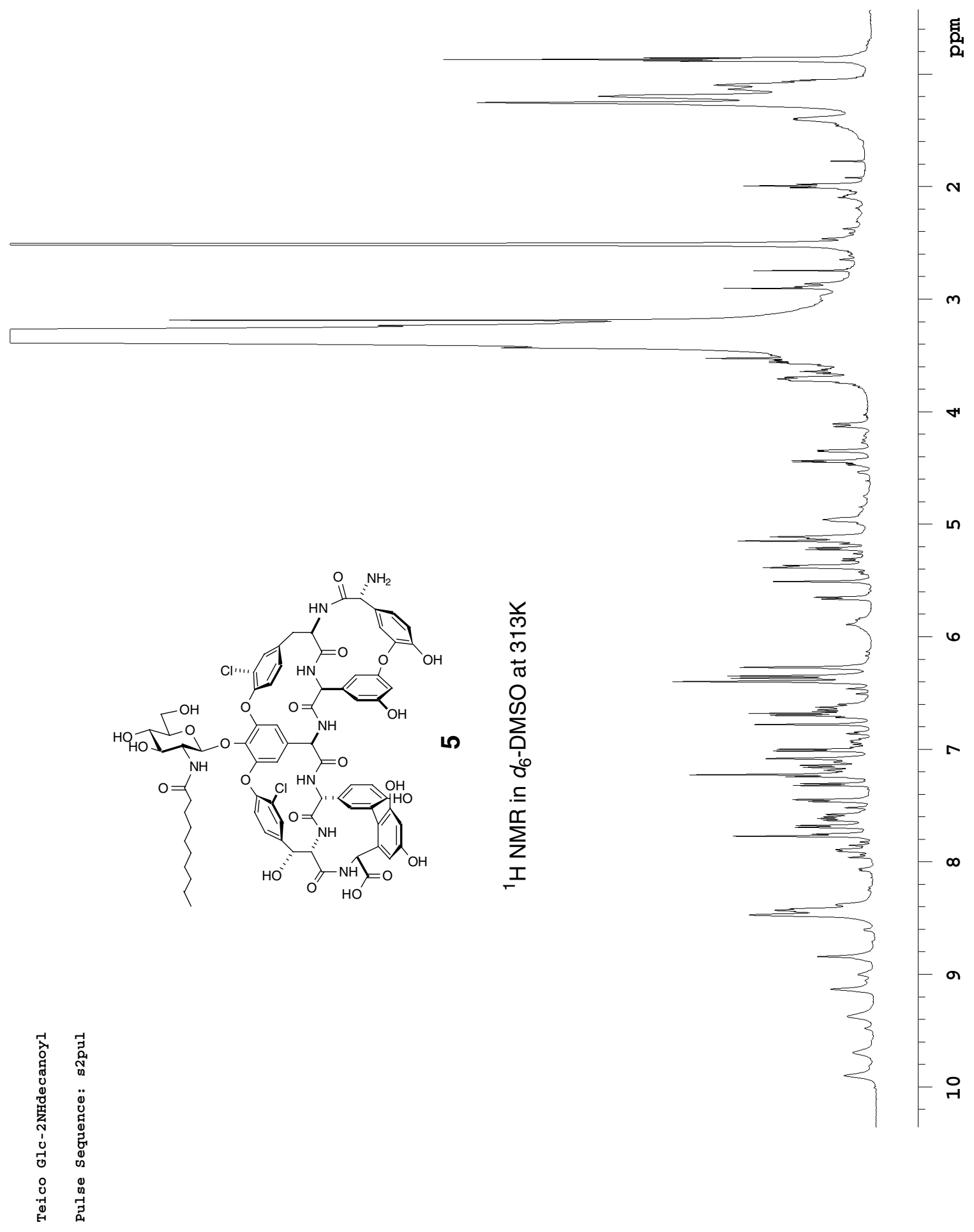




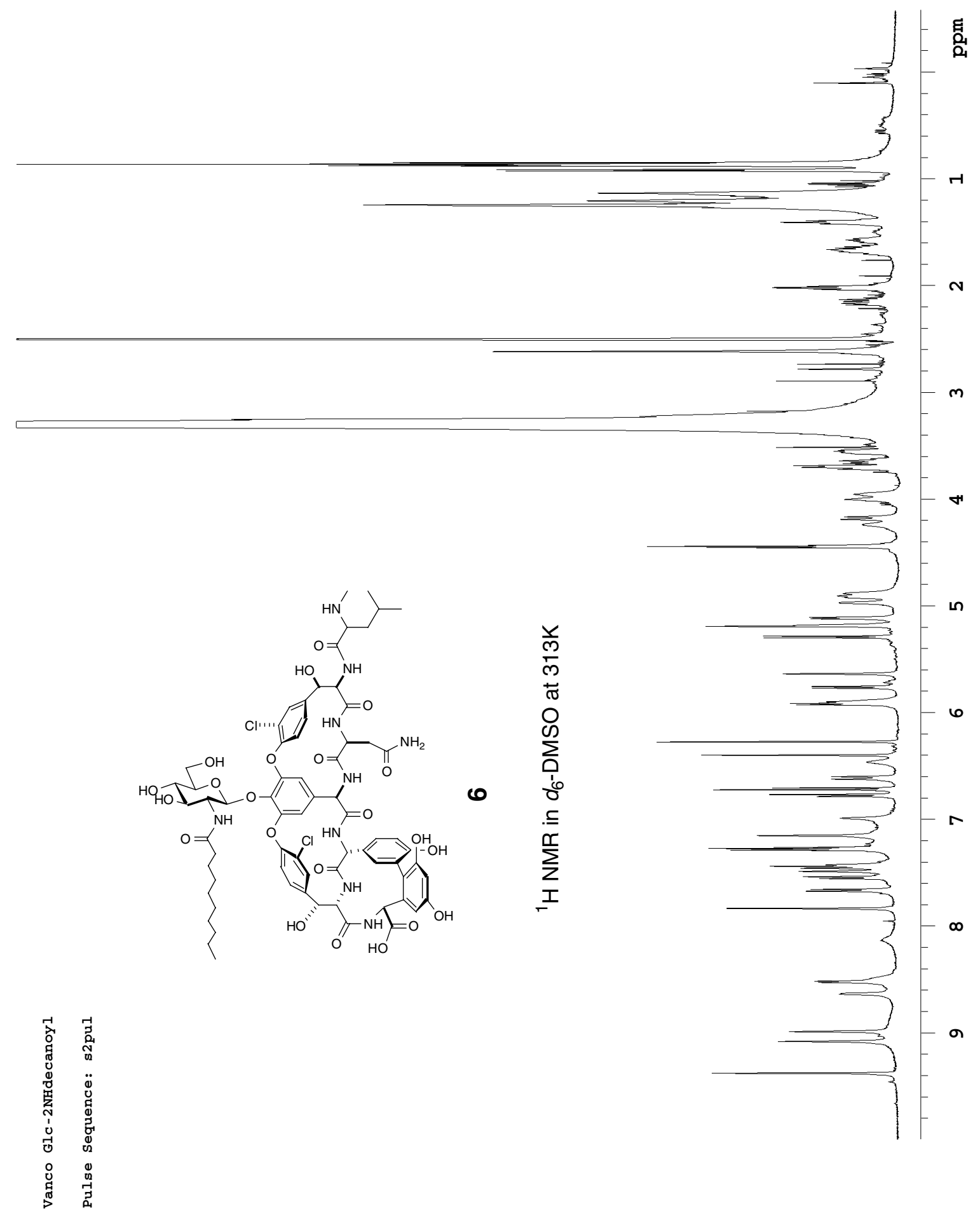

